(C) Dr W. Junk Publishers, Dordrecht - Printed in the Netherlands

\title{
Aquatic Oligochaeta in some tributaries of the Río de La Plata, Buenos Aires, Argentina
}

Celia Gluzman de Pascar

Instituto de Embriología, Biología e Histología, Facultad de Ciencias Médicinas, Universidad Nacional de la Plata, La Plata 1900, Argentina

Keywords: aquatic Oligochaeta, neotropical species, Río de La Plata tributaries, pollution, atypical penis-sheaths, Argentina

\begin{abstract}
The Oligochaeta of some streams flowing into the Río de La Plata, Buenos Aires, Argentina, were investigated. Twenty nine taxa (twenty four naidids, five tubificids) were identified. Most species are cosmopolitan, but Dero evelinae, Pristina leidyi, Slavina isochaeta and Bothrioneurum sp. are neotropical. Bratislavia unidentata, Haemonais waldvogeli and Nais pardalis are reported for the first time in Argentina. Variants occurr in the shape of the distal end of the penial sheaths of Limnodrilus hoffmeisteri. The dominant Naidid genera are Dero and Pristina. In the polluted El Gato stream only L. hoffmeisteri and L. claparedeianus were found.
\end{abstract}

\section{Introduction}

The freshwater Oligochaeta of Argentina were studied by Cernosvitov, 1937; Gavrilov, 1970, 1977, 1981; Di Persia, 1973, 1974, 1975, 1976, 1977, 1978, 1980, 1981; and recently Gluzman de Pascar, 1984; Pujals, 1984 and Varela et al., 1983. These contributions deal with the North- East and other isolated geographic areas of the country and there is no knowledge on the rest of Argentina. Yet, Buenos Aires Province has a rich net of rivers and a number of streams which are tributaries of the Río de La Plata. I here present the first results on the oligochaetes of Buenos Aires Province.

\section{Study area}

Eleven running waters were studied. Ten are situated near the coast of the Río de La Plata, but one, El Azul stream, is located in the interior of the Province. They are shallow, but seasonally increase in volume after the rains. El Gato stream is heavily polluted by domestic sewage, cellulose waste from a paper industry and oil subproducts from large steel works. In Rodriguez stream, a cold-storage house causes pollution (Fernández et al., 1977).

\section{Methods}

The littoral sediments were sampled bimonthly from November 1983 to June 1985 (nine samples per locality, at two different stations). In the laboratory, living specimens were sorted at $10 \mathrm{X}$ magnification and fixed in 5\% formalin. Whole mounts were identified following Brinkhurst \& Jamieson, 1971 and Harman, 1974, 1978.

\section{Results}

\section{Systematic comments}

Twenty nine species of oligochaets were identified (twenty four Naidids and five Tubificids). Representatives of the Aeolosomatidae, Enchytraeidae, Lumbriculidae and Opistocystidae were not identified to species. Table 1 gives a list of taxa and their distribution. The number of Naidi- 
Table 1. List of taxa identified in eleven tributaries of the Rio de La Plata. The number of sampling localities is given between brackets. An asterisk indicates new records for Argentina.

Taxon

\section{NAIDIDAE}

Bratislavia unidentata ${ }^{+}$Harman

Dero digitata Müller

(6-8-9)

D. evelinae Marcus

D. nivea Aiyer

D. plumosa Naidu

Dero sp. I

Dero sp. II

Dero sp. III

D. (Aulophorus) furcatus Müller

D. (Aulophorus) sp. I

D. (Aulophorus) sp. II

Haemonais waldvogeli Bretscher ${ }^{+}$

Nais communis Piguet

N. elinguis Müller

N. pardalis Piguet ${ }^{+}$

Pristina breviseta Bourne

$P$. aequiseta Bourne

$P$. idrensis Sperber

$P$. leidyi Smith

$P$. notopora Cernosvitov

Pristina sp. I

Slavina isochaeta Cernosvitov

Slavina sp.

Stephensoniana trivandrana Aiyer

(6)

(8)

(5)

(5-6)

(6)

(10)

(8)

(3-6-8)

(6)

(8)

(6)

(6-9)

(11)

$(6-7-11)$

(7-9)

(7-8-9)

(2-3-5-6-8)

(8)

(6-11)

(9)

(3-9)

TUBIFICIDAE

Aulodrilus limnobius Bretscher

A. pigueti Kowalewski

Bothrioneurum sp

(6)

Limnodrilus claparedeianus Ratzel

(1-6-9-11)

(1-3-4-5-6-7-8-9-11)

L. hoffmeisteri Clapárede

AEOLOSOMATIDAE

$(1-3-8-9-10)$

ENCHYTRAEIDAE

LUMBRICULIDAE

(1-3-6-9-11)

(6-10)

OPISTOCYSTIDAE

References

Streams- 1: El Gato; 2: La Guardia; 3: Rodriguez; 5: Martín; 5: El Carnaval; 6: Baldovino; 7: El Pescado; 8: Zapata; 11: El Azul.

Canal- 9: La Balandra; 10: Atalaya, Río de la Plata.

dae is much higher than that of Tubificidae, and Dero and Pristina are the genera richest in species.

Most Naididae identified are cosmopolitan, but four are neotropical: $D$. evelinae, $P$. leidyi, $S$. isochaeta and Bothrioneurum sp. Three species are new to Argentina: Bratislavia unidentata, Haemonais waldvogeli and Nais pardalis (Table 1). $P$. idrensis and $L$. hoffmeisteri had a wide distribution

in the lotic waters studied (Table 1). The highest species richness was found in El Baldovino stream (eighteen species), while, the number of species was particularly low in the Martín and El Gato streams (Table 1).

Nais communis was reported, without locality record, from Patagonia (Michaelsen \& Bolt, 1932). Some specimens in El Baldavino stream and a large population in La Balandra canal, near the $\mathrm{R}$ io de La Plata, were found. B. unidentata, immature and mature, was collected from Baldovino and Zapata streams and from La Balandra canal. $H$. waldvoge$l i$ was found only in Baldovino stream, and $N$. pardalis inhabits Baldovino, El Pescado and El Azul streams. The Tubificidae were less varied and represented by five species (Table 1). L. claparedeia$n u s$ and $L$. hoffmeisteri showed the widest distribution.

Specimens of $L$. hoffmeisteri with atypical sheaths were observed in El Gato and El Pescado streams (Fig. 1). The distal end of the sheaths differs from variants described by Maciorowski (1977). My L. hoffmeisteri presented in one case, a distal end lacking the reflected lobe, but possessing two deep incisions on the sheath wall. Another variant showed the two incisions and a small reflected lobe (Fig. 1), but the latter could be a mounting artifact.

Aeolosomatidae occurred in El Gato, Rodriguez and Zapata streams and in La Balandra canal, and on the sands of the Río de La Plata at a side called Atalaya. Immature Lumbriculidae were found in Baldovino stream. Opistocystidae were collected in La Balandra canal.

El Gato and Martín streams have only tubificids and lack naidids. Rodriguez stream with seven species cannot be considered highly polluted as did Fernández et al.

\section{Taxonomic remarks}

Family Naididae

Bratislavia unidentata (Harman, 1973)

Material examined: 20 immature and mature worms from Baldovino and Zapata streams and from La Balandra canal.

Length (preserved) 6-8 mm; living $2 \mathrm{c}$; diameter (preserved) $250 \mu \mathrm{m} ; 32$ segments. Prostomium 

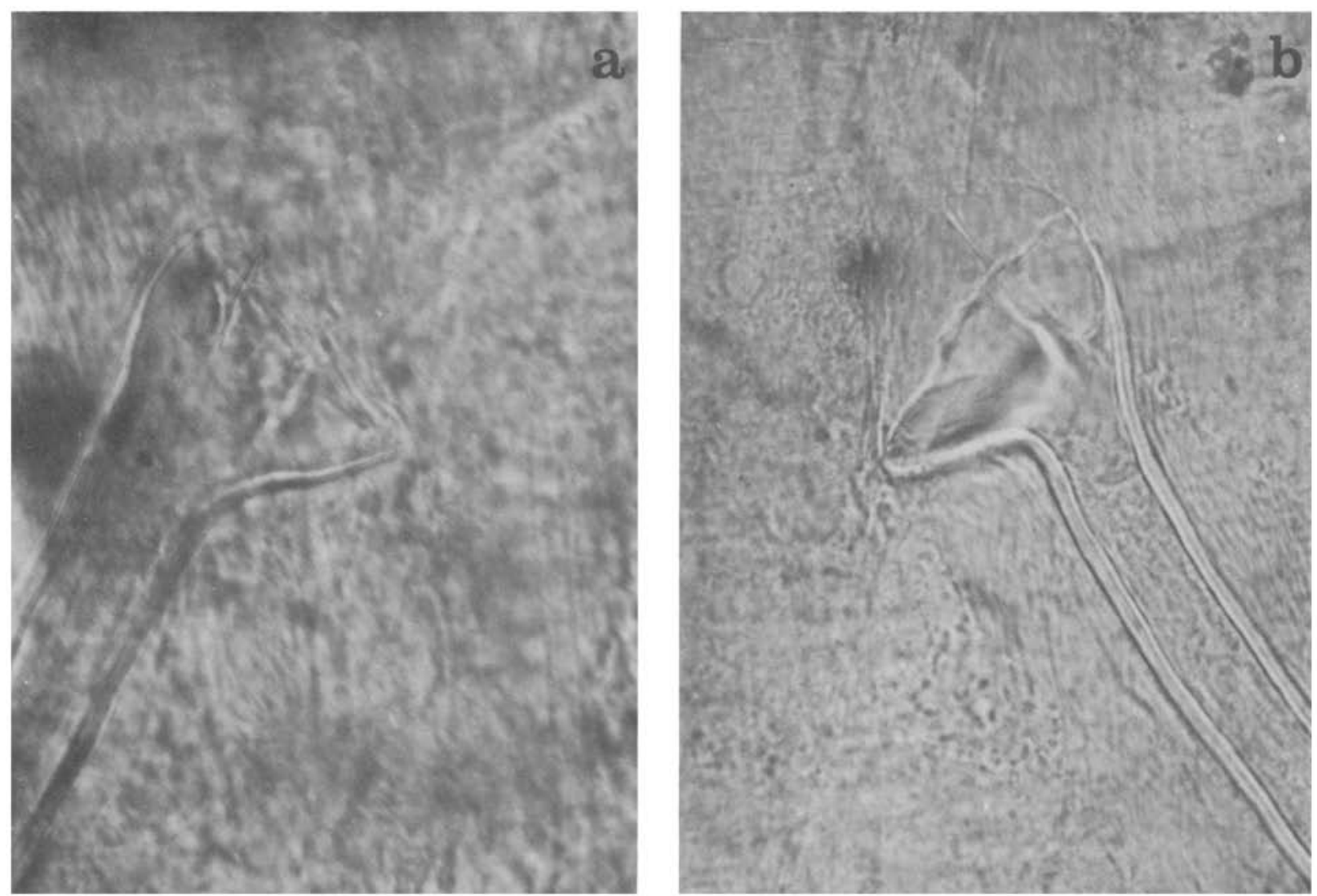

Fig. I. Atypical penis sheaths of L. hoffmeisteri. $400 \times$

a: distal end with two deep incisions without any reflected lobe; b: second variant with two deep incisions and a reflected lobe.

moderately triangular, without proboscis, Dorsal fascicles from II, one simple-pointed seta S-shaped, stout, with distal nodulus. Segments II-III and sometimes up to V without hair setae (Fig. 2). Dorsal fascicles posterior to $\mathrm{V}$ with 1 smooth hair setae, frequently absent in posterior segments. Ventral setae 2-4 per bundle; in II-V, 4 per bundle decreasing in number on posterior segments. Ventral setae on II-V slender, $90 \mu \mathrm{m}$ long; upper tooth thinner than lower. Ventral setae posterior to segment $\mathrm{V}$ stout with teeth equally long and upper tooth thinner than lower (Fig. 3).

Mature worms in February. Clitellum from the middle of segment V to VII-VIII. Spermathecae between segments IV-V; atria in VI, difusse prostate surrounding atria and a large sperm sac from segments VII to IX. Penial setae $2-3$ per bundle in segment VI, simple-pointed, hooked (Fig. 4).

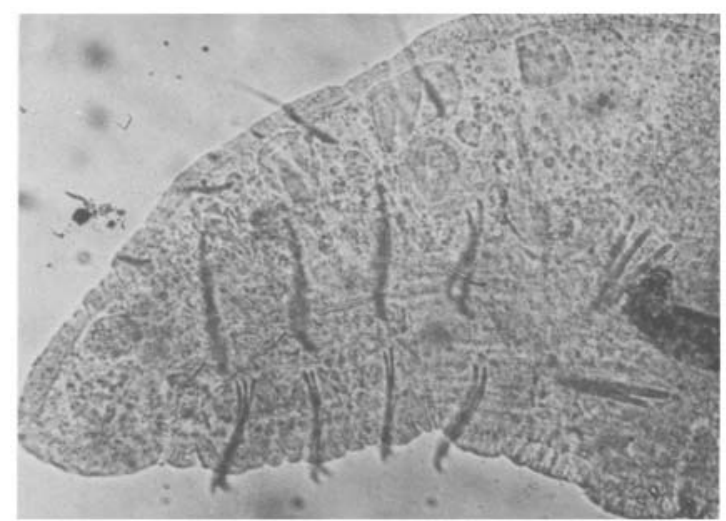

Fig. 2. B. unidentata: mature. Prostomium and first segments. Dorsal and ventral setae. $100 \times$ 


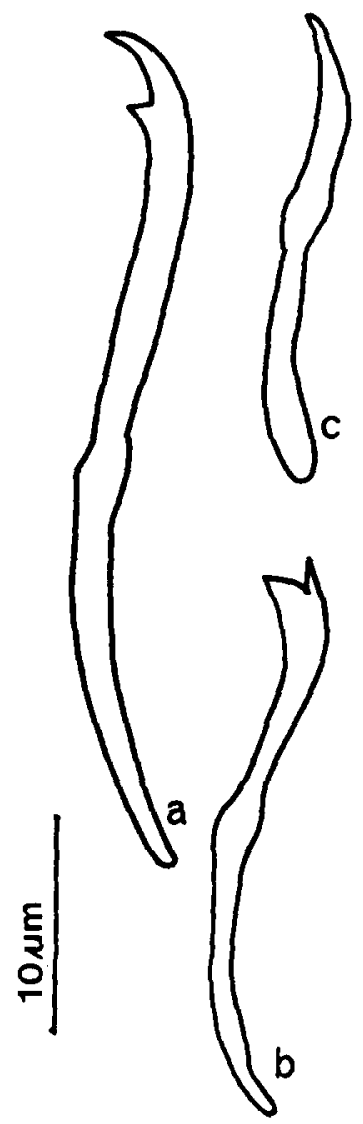

Fig. 3. B. unidentata: dorsal and ventral setae. $400 \times$ a: ventral seta from II; b: posterior ventral seta; $c$ : dorsal needle from II.

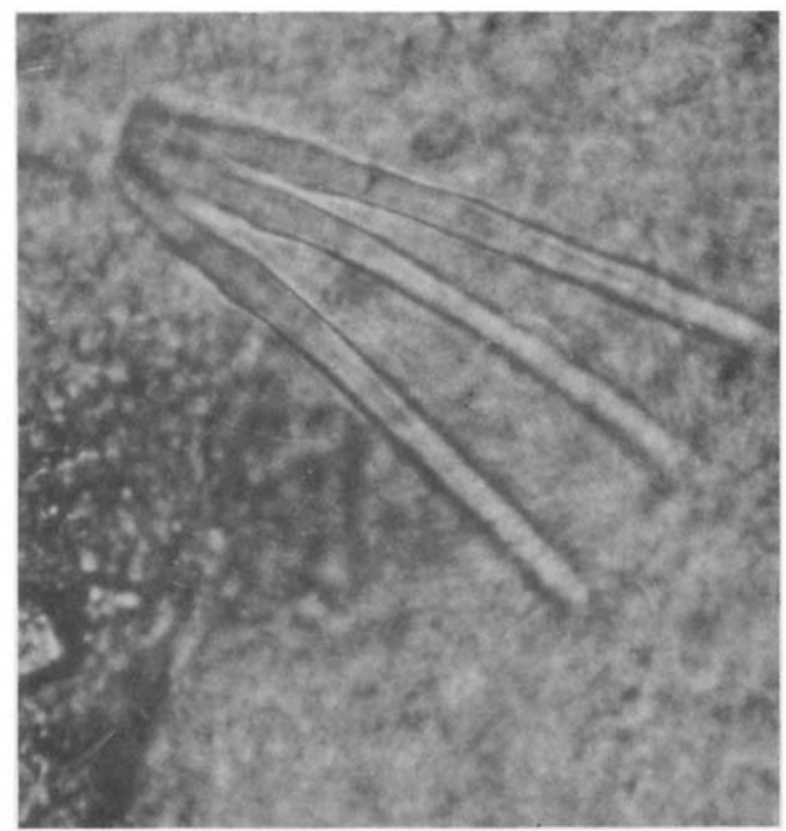

Fig. 4. B. unidentata. Penial setae. $400 \times$
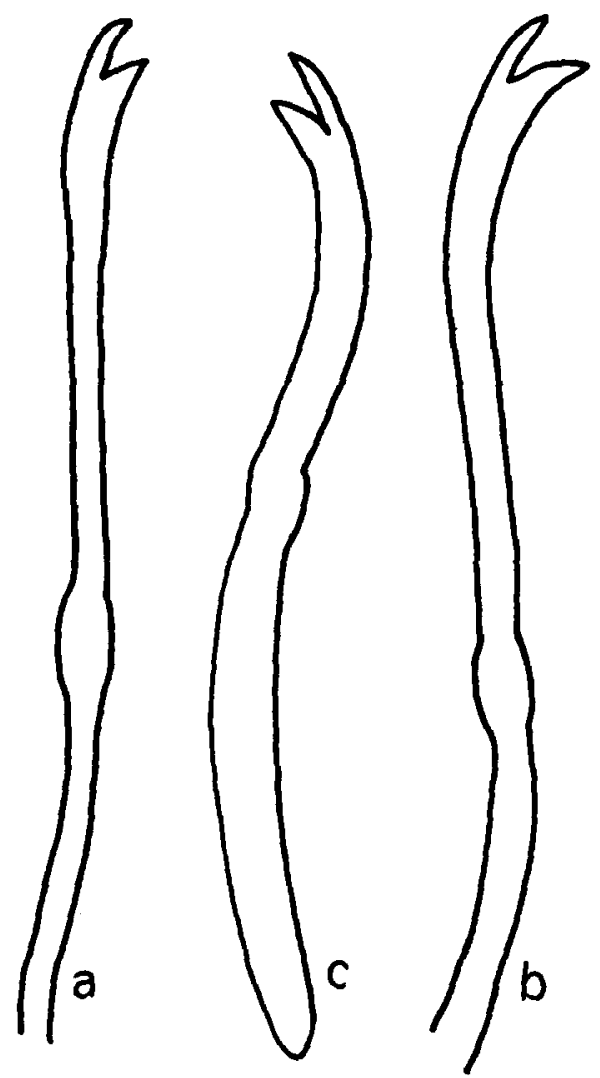

Fig. 5. H. waldvogeli: a, ventral seta of III; b, posterior ventral seta; c, dorsal seta of XII.

Haemonais waldvogeli (Bretscher, 1900)

Material examined: 2 immature worms from Baldovino stream.

Length (preserved) $10 \mathrm{~mm}$; $\mathrm{s}: 20-49$ (worms in budding). Dorsal setae bundles beggining on XII in one specimen and on XX in the other, usually with one short hair and one curved needle seta with distal nodulus and long teeth, the upper tooth longer. Ventral setae $2-6$ per bundle, on anterior segments with proximal nodulus, and from XVII onwards more curved and slightly thicker, with teeth equally long but the lower thicker and stronger (Fig. 5).

Nais pardalis (Piguet, 1906)

Material examined: 16 immature worms from Baldovino, El Pescado and El Azul streams.

Lengths (preserved) 6-8 mm; 20 segments. Dorsal setae from VI. Needles $1-2$ per bundle with nodulus about $1 / 3$ from the tip and fine, equal 


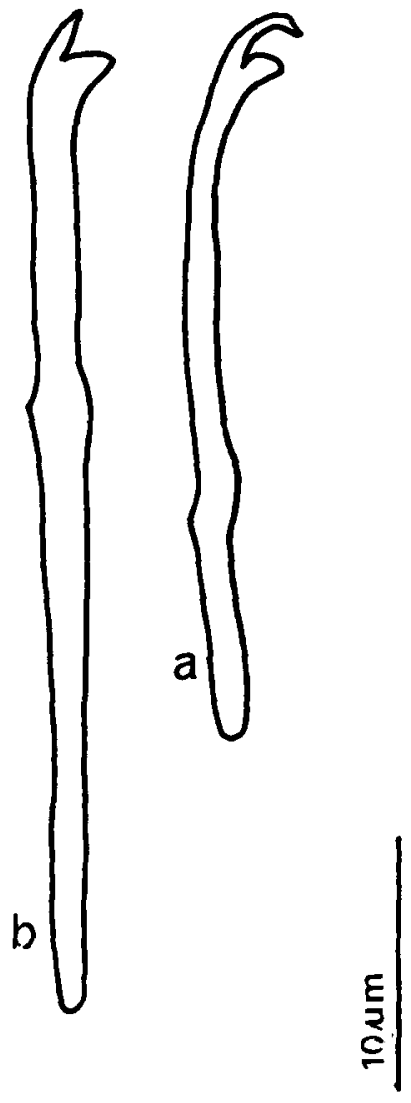

Fig. 6. N. pardalis. a: ventral seta of II; b: posterior ventral seta.

teeth; hairs usually one per bundle; when two are present, one is very short. Ventral setae of II-V, 5 per bundle with upper tooth $1 \frac{1 / 2-2}{\text { times as long }}$ as lower and nodulus median or slightly proximal; from VI on, 5 setae per bundle with distal nodulus and thick setae with equal teeth (Fig. 6).

\section{Acknowledgements}

The author thanks Dr. C. L. Gómez Dumm for his advice on the manuscript and Dr. W. H. Harman for sending reprints and drawings of $B$. unidentata.

\section{References}

Brinkhurst, R. O. \& B. G. M. Jamieson, 1971. Aquatic Oligochaeta of the World. Oliver \& Boyd, Edinb., 860 pp.
Cernosvitov, L., 1937. Notes sur les Oligochaeta (Naididées et Enchytraedées) de l'Argentine. An. Mus. nac. Cienc. nat. Rivadavia, B. 39: 135-157.

Di Persia, D. H., 1973. Notas sobre Oligoquetos dulciacuícolas argentinos. Physis 32: 279-285.

Di Persia, D. H., 1974. Sobre algunos oligoquetos dulceacuícolas del área comprendida entre Santa Fe y Paraná. Revta. Asoc. Cienc. nat. Litoral 5: 33-44.

Di Persia, D. H., 1974. Géneros, subgéneros y especies de oligoquetos dulceacuícolas de las familias Naididae y Aeolosomatidae registrados en cuencas leníticas próximas a las ciudades de Santa Fe y Paraná. Revta. Asoc. Cienc. nat. Litoral 5: $89-98$.

Di Persia, D. H., 1975. Oligoquetos del subgénero Aulophorus Schmarda nuevos para fauna acuática argentina (Dero, Naididae). Comun. Cient. Cecoal 2: 1-17.

Di Persia, D. H., 1975. Sobre algunas especies y un género de oligoquetos nuevos para Argentina. Comun. Cient. Cecoal 4: $1-8$.

Di Persia, D. H., 1975. Acerca de dos especies del género Nais de Argentina (Oligochaeta, Naididae). Neotrópica 21: $131-134$.

Di Persia, D. H., 1976. Nuevas citas del género Dero s. s. (Naididae, Tubificoidea) para la oligoquetofauna acuática argentina. Physis 35: 1-7.

Di Persia, D, H., 1977. Adición al conocimiento del subgénero Dero (Oligochaeta, Naididae). Neotrópica 23: 11-16.

Di Persia, D. H., 1978. Clave para la determinación de géneros y subgéneros de Naididae del nordeste argentino. Revta. Asoc. Cienc, nat. Litoral 9: 1-12.

Di Persia, D. H., 1980. The Aquatic Oligochaeta of Argentina: Current status of knowledge. In: R. O. Brinkhurst \& D. G. Cook (eds), Aquatic Oligochaete Biology, Plenum Press, N.Y., 225-240.

Di Persia, D. H., 1981. Sobre algunos oligoquetos acuáticos del norte de Mendoza. Comun. Cient. Cecoal 10: 1-14.

Fernández, L. \& L. A. Schnack, 1977. Estudio preliminar de la meiofauna en tramos poluídos de los arroyos Rodriguez y Carnaval (Provincia de Buenos Aires). Ecosur 4: 103-115.

Gavrilov, K., 1970. Nota faunística sobre $L$. claparedeianus Ratzel (Tubificidae, Oligochaeta). Acta zool. lilloana 26: $145-156$.

Gavrilov, K., 1977. Oligochaeta. In: S. H. Hurlbert (ed), Biota acuática de Sudamérica Austral, San Diego St. Univ., San Diego, California: 99-121.

Gavrilov, K., 1981. Oligochaeta. In: S. H. Hurlbert (ed), Aquatic biota of Tropical South America. Part II, San Diego St. Univ., San Diego, California: 170-190.

Gluzman de Pascar, C., 1984. Primeros registros de la oligoquetofauna dulciacuícola en aguas lóticas y leníticas de la Provincia de Buenos Aires. VII J. Arg. de Zool., Mar del Plata, Argentina. RESUMENES.

Harman, W. J., 1974. The Naididae (Oligochaeta) of Surinam. Zool. Verh. 133: 1-36.

Harman, W. J. \& M. S. Loden, 1978. Bratislavia unidentata (Oligochaeta: Naididae), a re-description. Southwest. Nat. 23: $541-544$.

Maciorowski, A. F., E. F. Benfield \& A. D. Hendricks, 1977. Species composition, distribution and abundance of oligochaetes in the Kanawha river, West Virginia. Hydrobiologia 54: $81-91$. 
Marchese, M. E. \& I. Ezcurra de Drago, 1983. Zoobentos de los principales tributarios del Río paraná Medio en el tramo Goya-Diamante. Su relación con el cauce principal y cauces secundarios. Rev. Asoc. Cienc. nat. Litoral 14: 95-109.

Michaelsen, W. \& W. Boldt, 1932. In: A. Thienemann (ed), Oligochaeten der deutschen limnologischen SundaExpedition. Tropische Binnengewasser II. Arch. Hydrobiol. Supl. 9: 587-622.

Pujals, M. A., 1984. Contribución al conocimiento de los Oligo- quetos límnicos de la Provincia de Buenos Aires. VII J. Arg. de Zool., Mar del Plata, Argentina. RESUMENES.

Varela, M. E., J. A. Bechara \& N. L. Andreani, 1983. Introdución al estudio del bentos del Alto Paraná. Ecosur 19: $103-126$.

Received 4 September 1984; in revised form 20 June 1986; accepted 1 August 1986. 